P 421.8

$\operatorname{su} 18$

1987

Successful Spawning of

Orangemouth Corvina Following Injection

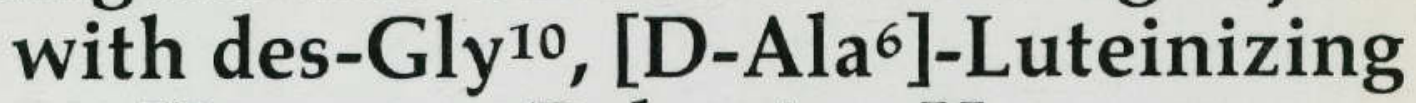

Hormone-Releasing Hormone (1-9) Ethylamide and Pimozide

by

John A. Prentice

Peter Thomas

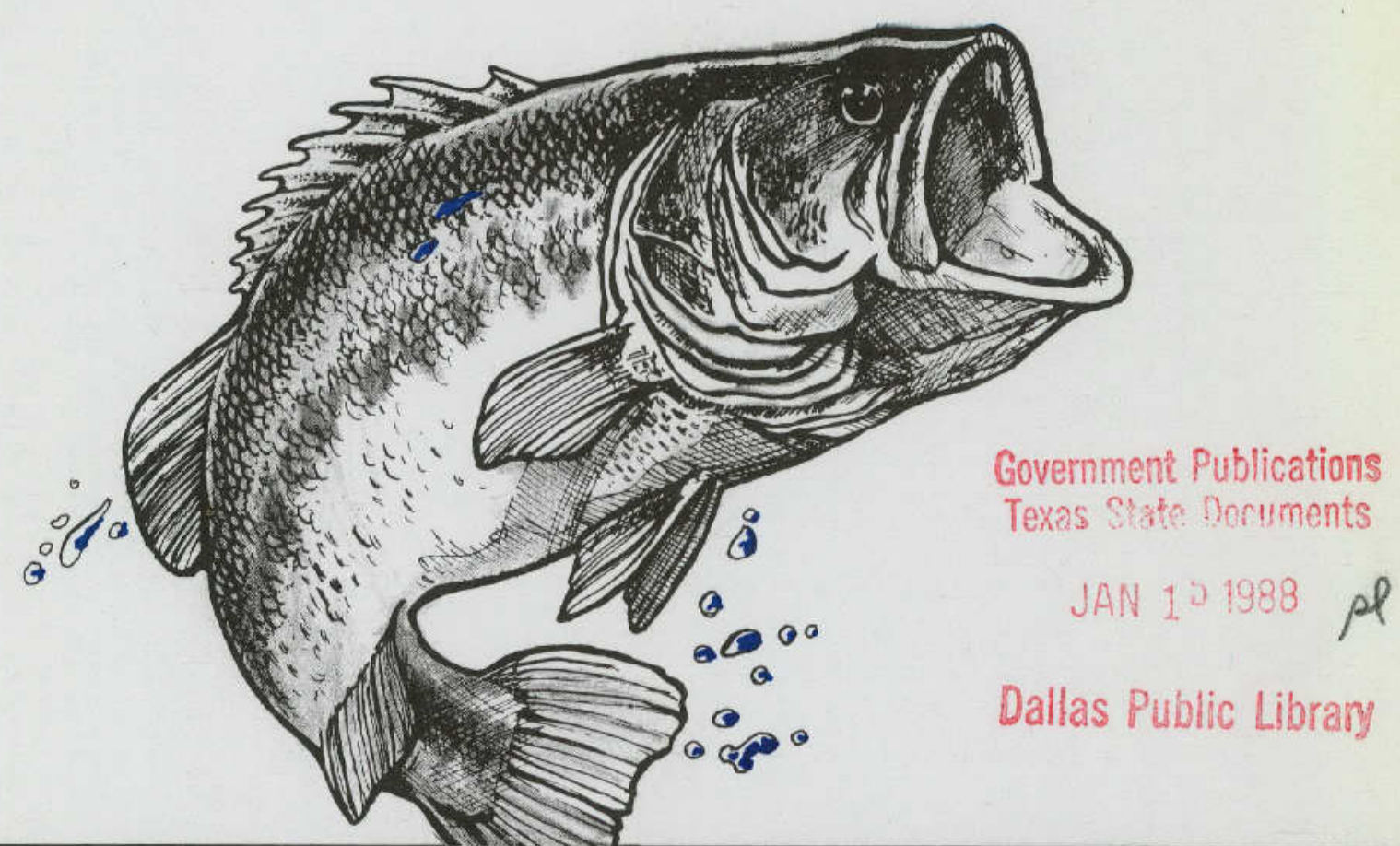

TEXAS PARKS \& WILDLIFE DEPARTMENT

NLAND FISHERIES

IMPROVING THE QUALITY OF FISHING 


\author{
Successful spawning of \\ Orangemouth Corvina Following Injection with \\ des-Gly $y^{10}$, $\left[d-A l a^{6}\right]$-Luteinizing Hormone-Releasing Hormone \\ (1-9) Ethylamide and Pimozide
}

by

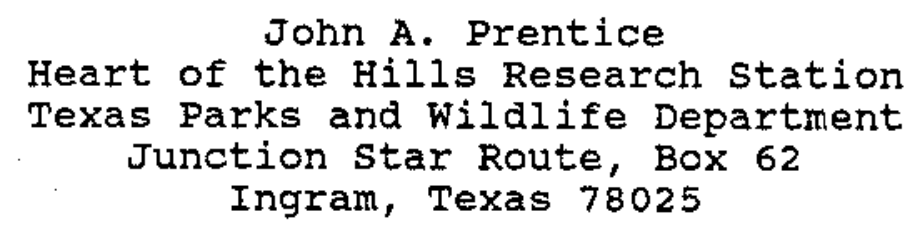

and

Peter Thomas

University of Texas Marine Science Institute

Port Axansas, Texas 78373 


\section{Successful Spawning of Orangemouth Corvina Following Injection with

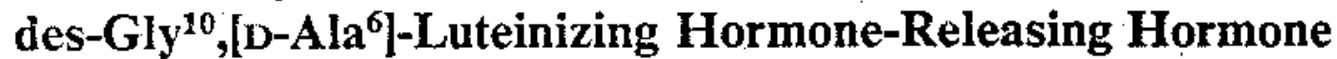 (1-9) Ethylamide and Pimozide}

\author{
JOHN A. PRENTICE
}

Heart of the Hills Research Station

Texas Parks and Willdife Department

Junction Star Route, Box 62

Ingram, Texas 78025, USA

\section{Peter Thomas}

University of Texas Marine Science Institute Port Aransas, Texas 78373 , USA

Abstract.-Two attempts to spawn mature orangemouth corvina (Cynoscion xanthulus) with hormone injections resulted in successful spawns. Spawns with high fertilization rates $(86.9 \pm 11.8 \%$ and $84.4 \pm 5.9 \%)$ followed injections of des-Gly ${ }^{10},\left[0-\mathrm{Ala}^{6}\right]$-futeinizing hormone-releasing hormone (1-9) ethylamide $(0.10-0.20$ $\mathrm{mg} / \mathrm{kg}$ fish body weight) and pimozide $(5.0-10.0 \mathrm{mg} / \mathrm{kg}$ fish body weight). This treatment may be useful for inducing ovulation in other species which have been difficult to breed by traditional methods in captivity.

Efforts to artificially breed orangemouth corvina (Cynoscion xanthulus), an important sport fish in the Salton Sea, California, have been hampered by a lack of information about the reproductive biology of the species. Gonadal recrudescence in orangemouth corvina has been induced in captivity by a photoperiod-temperature regime that mimics Salton Sea conditions (Prentice and Colura 1984). Traditional methods of inducing ovislation by injection with heterologous mammalian gonadotropin preparations, human chorionic gonadotropin (HCG) and pregnant mare serum gonadotropin (PMSG) have not been entirely successful (Prentice and Colura 1984; G. Lattin, Occidental College, Los Angeles, personal communication).

Recent studies suggest that the ovulatory surge in gonadotropin secretion in several teleost species may depend upon release of gonadotropin-releasing hormone (Gn-RH) from neurosecretory fibers in the anterior pituitary and a decline in gonadotropin release-inhibiting factor (GR-IF) secretion (Chang et al. 1983). The structure of a teleost $\mathrm{Gn}-\mathrm{RH}$ has been elucidated and appears similar to mammalian luteinizing hormone-releasing hor- mones (LH-RH; Sherwood et al. 1983). In addition, dopamine has been shown to have GR-IF activity in fish, although it is not yet known whether other factors also have GR-IF activity (Peter 1983; Groves and Batten 1986).

Considerable potential exists for application of these recent advances in understanding of the neuroendocrine control of ovulation in fishes to artificially induce ovulation and spawning of important species in captivity. This paper reports preliminary use of a luteinizing hormone-releasing hormone analog, des-Gly ${ }^{10},\left[\mathrm{D}-\mathrm{Ala} \mathrm{a}^{6}\right]$-luteinizing hormone-releasing hormone (1-9) ethylamide (LH-RHa), and pimozide (a dopamine antagonist) injections to induce final egg maturation and ovulation in orangemouth corvina.

Orangemouth corvinas were collected from the Salton Sea as subadults (146-345 mm total length, TL), transported to the Heart of the Hills Research Station, Ingram, Texas, and reared to adult size in two indoor aquaria as described by Prentice and Colura (1984). Seawater, salinity $28-32 \%$, was made by adding artificial sea salt (Fritz Super Salt, Fritz Chemical Company, Dallas, Texas) to fresh spring water obtained at the research station. Fish were fed live goldfish (Carassius auratus) and dead shrimp (Penaeus spp.) at approximately 5\% of fish body weight per day.

Gonadal recrudescence was stimulated by exposing fish to photoperiod and water temperature conditions simulating seasonal changes that would be expected to occur in the Salton Sea. Annual seasonal cycles of photoperiod and temperature were condensed to 6 months in the laboratory by arbitrarily assigning 6 weeks to each season. Photoperiod and temperature ranges for each season were as follows: winter, 9.0-10.4 h light and 18.9$24.4^{\circ} \mathrm{C}$; spring, $10.5-14.5 \mathrm{~h} \mathrm{light}$ and $19.4-25.6^{\circ} \mathrm{C}$; summer, $14.6-15.0 \mathrm{~h}$ light and $23.3-30.0^{\circ} \mathrm{C}$; and fall, $10.5-14.5 \mathrm{~h}$ light and $22.2-28.9^{\circ} \mathrm{C}$. Fish were inspected at least once each month to monitor sexual development. They were anesthetized as described by Prentice and Colura (1984) prior to each inspection and sampling. Intraovarian samples were collected by a catheter inserted via the 
TABLE 1.-Orangemouth corvina spawning statistics following intramuscular injection of luteinizing hormonereleasing hormone analog (LH-RHa) and pimozide, Heart of the Hills Research Station, Ingram, Texas, 1986.

\begin{tabular}{|c|c|c|c|c|c|c|c|c|c|}
\hline \multicolumn{2}{|c|}{ Female size } & \multicolumn{2}{|c|}{$\begin{array}{l}\text { Mean (range) oocyte } \\
\text { dismeter (mm) }\end{array}$} & \multicolumn{2}{|c|}{$\begin{array}{c}\text { Injection rate } \\
\text { (mg inducer } / \mathrm{kg} \text { body weight) }\end{array}$} & \multirow{2}{*}{$\begin{array}{l}\text { Time } \\
\text { from first } \\
\text { injection } \\
\text { to start of } \\
\text { spawning } \\
\text { (h) }\end{array}$} & \multirow{2}{*}{$\begin{array}{l}\text { Total eggs } \\
\text { spawnedb } \\
\text { (SD) }\end{array}$} & \multirow{2}{*}{$\begin{array}{l}\% \text { of } \\
\text { eggs fer- } \\
\text { tilizedc } \\
\text { (SD) }\end{array}$} & \multirow{2}{*}{$\begin{array}{c}\% \\
\text { hatch } \\
\text { (SD) }\end{array}$} \\
\hline $\begin{array}{l}\text { Total } \\
\text { length } \\
(\mathrm{mm})\end{array}$ & $\begin{array}{l}\text { Weight } \\
(\mathrm{kg})\end{array}$ & Day 1 & spawning & Day 1 & Day 3 & & & & \\
\hline \multicolumn{10}{|c|}{ Experimental day 1: March 24} \\
\hline 635 & 2.5 & $\begin{array}{c}0.47 \\
(0.33-0.53)\end{array}$ & $\begin{array}{c}0.26 \\
(0.05-0.83)\end{array}$ & $\begin{array}{c}\text { LH-RHa: } \\
0.20 \\
\text { Pimozide: } \\
10.0\end{array}$ & $\begin{array}{l}\text { LH-RHa: } \\
0.1\end{array}$ & \multicolumn{4}{|l|}{$\cdot$} \\
\hline 673 & 2.6 & $\begin{array}{c}0.47 \\
(0.14-0.53)\end{array}$ & 0.05 & $\begin{array}{c}\text { LH-RHa: } \\
0.20 \\
\text { Pimozide: } \\
10.0\end{array}$ & $\begin{array}{l}\text { LH-RHa: } \\
0.1\end{array}$ & $72^{\circ}$ & $\begin{array}{l}624,000^{6} \\
(32,900)\end{array}$ & $\begin{array}{r}86.90 \\
(11.8)\end{array}$ & $\begin{array}{r}69.6^{\mathrm{e}} \\
(31.5)\end{array}$ \\
\hline 603 & 1.9 & $\begin{array}{c}0.36 \\
(0.20-0.47)\end{array}$ & $\begin{array}{c}0.44 \\
(0.05-0.57)\end{array}$ & Control & . & $\begin{array}{l}\text { No } \\
\text { spawn }\end{array}$ & & & \\
\hline \multicolumn{10}{|c|}{ Experimental day 1 ; April 28} \\
\hline 813 & 7.0 & $\begin{array}{c}0.46 \\
(0.40-0.50)\end{array}$ & $\begin{array}{c}0.0 .5 \\
(0.05-0.50)\end{array}$ & $\begin{array}{c}\text { LH-RHa: } \\
0.13 \\
\text { Pimozide: } \\
5.0\end{array}$ & . & 30 & $\begin{array}{r}1,272,000 \\
(218,000)\end{array}$ & $\begin{array}{l}84.4 \\
(5.9)\end{array}$ & $\begin{array}{l}65.4 \\
(3.1)\end{array}$ \\
\hline 832 & 7.8 & $\begin{array}{c}0.51 \\
(0.47-0.53)\end{array}$ & $\begin{array}{c}0.49 \\
(0.40-0.53)\end{array}$ & Control & & $\begin{array}{l}\text { No } \\
\text { spawn }\end{array}$ & & & $\therefore$ \\
\hline
\end{tabular}

At injection times, photoperiods were $12-10 \mathrm{~h}$ light (decreasing) and water temperatures were $23-27^{\circ} \mathrm{C}$.

b Number of eggs spawned was estimated by at least three volumetric subsamples from each experiment.

c Percent fertilization was deternined by examining three samples of approximately 100 eggs each for mitotic division.

¿ Percent hatch was determined by counting larvae resulting from three samples of approximately 100 eggs each incubated in 20 $30 \mathrm{~L}$ of culture water.

e Spawning results are from both injected females.

oviduct. Oocytes (50-100) from each female (identified by fin ciips) were examined for yolk deposition and their diameters were measured (to the nearest $0.01 \mathrm{~mm}$ ) with an ocular micrometer at $40 \times$ magnification. Males, eight $(470-660 \mathrm{~mm}$ TL) for the March 24 experiment and four (775$914 \mathrm{~mm} \mathrm{TL}$ ) for the April 28 experiment, were considered to have fully mature testes when milt was released upon application of light abdominal pressure. Sexual maturation in males and females was first observed several weeks after photoperiod had been increased to $15 \mathrm{~h}$ light.

Two of the three tagged females in one aquarium were administered hormone injections on March 24 (day 1) and March 26 (day 3) while the third female was not injected (Table 1). One of the two tagged females in the other aquarium was administered a single hormone injection on April 28 (day 1) while the other female was not injected (Table 1). The uninjected females served as controls. Fish were anesthetized and injected intramuscularly below the dorsal fin. The LH-RHa (Sigma Chemical Company, St. Louis, Missouri) was dissolved in $3 \mathrm{~mL}$ acidified saline (pH 6) for injection. Pimozide, a gift from Wildlife Labora- tories Incorporated, Boulder, Colorado (manufacturer: Janssen Pharmaceuticals Limited, Beerse, Belgium), was injected as a suspension, also in acidified saline. Males did not receive hormone injections. Fish were allowed to spawn naturally in the aquaria.

Spawning, determined by direct observation, began just before dusk approximately $72 \mathrm{~h}$ after the first injection in March and $30 \mathrm{~h}$ after the single injection in April, and continued on subsequent evenings for up to $7 \mathrm{~d}$. High fertilization rates ( 86.9 and $84.4 \%$, respectively) were obtained in both spawns (Table 1). Egg incubation time at $24-25^{\circ} \mathrm{C}$ was approximately $24 \mathrm{~h}$, as was yolk-sac duration in developing larvae.

Intraovarian samples taken from all females 5 and $3 \mathrm{~d}$ after the beginning of spawning for the March and April experiments, respectively, suggested that injected females had spawned (Table 1). Ovaries from one female injected March 24 contained only small (about 0.05-mm-diameter) nonvitellogenic oocytes while the other injected female's ovaries contained oocytes in all stages of development from small (about $0.05-\mathrm{mm}$ ) nonvitellogenic to completely mature (about $0.83-\mathrm{mm}$, 
nonatretic) oocytes. Abdomens of both females injected March 24 appeared concave, suggesting many eggs had been spawned. The female injected April 28 had ovaries containing approximately $99 \%$ small (about $0.05-\mathrm{mm}$ ) nonvitellogenic oocytes, and her abdomen also appeared concave, again suggesting many eggs had been spawned. Uninjected females from both experiments maintained a gravid appearance, and their ovaries contained oocytes at stages of development very similar to those sampled from females before they were injected on day 1 . These observations suggest that spawning was the result of hormone treatment.

Mammalian gonadotropins have been used to stimulate artificial ovulation and spawning of a wide range of fish species in captivity (Donaldson and Hunter 1983). However, the optimal hormone dose for inducing ovulation varies considerably and thus has to be determined separately for each fish species. For orangemouth corvina, injection with $500-550$ international units (IU) $\mathrm{HCG} / \mathrm{kg}$ body weight (BW) caused a large percentage of the oocytes to ovulate and hydrate simultaneously, resulting in massive swelling of the ovary and subsequent death (Prentice and Colura 1984). Injections of PMSG (75-200 IU/ $/ \mathrm{kg} \mathrm{BW})$ in orangemouth corvinas induced ovulation in most individuals but spawning was only successful (12$72 \%$ fertilization) in three of eight attempts (G. Lattin, personal communication; Prentice, unpublished data). The PMSG injections caused a large percentage of orangemouth corvina oocytes to ovulate and hydrate simultaneously, as observed with HCG treatment, although no fish died. Many marine fishes are fractional spawners and normally only a small batch of fully matured eggs hydrate and are spawned at one time. However, marine fish eggs enlarge severalfold during hydration, causing the ovaries to swell considerably and fill the abdominal cavity. Consequently, marine fishes may be sensitive to excessive or abnormal ovarian stimulation by mammalian gonadotropins. Another possible disadvantage of heterologous mammalian gonadotropin treatment is that repeated administration to valuable brood stock can stimulate antibody production with a resulting loss of potency (Donaldson and Hunter 1983).

Ovulation can also be induced artificially in fishes by stimulating endogenous pituitary gonadotropin secretion with LH-RH analogs and dopamine blockers. Results of the present study show that this can be a useful method for inducing ovulation in fish when traditional methods using heterologous gonadotropins are unsuccessful. Further, this technique has several potential advantages over traditional methods. The LH-RH and pimozide treatment causes the normal ovulating agent, which is not autoimmunoreactive, to be released into the blood. Injection of orangemouth corvina with a high dose of LH-RHa and pimozide does not seem to cause simultaneous maturation and hydration of all the oocyies, suggesting this treatment is less likely than exogenous gonadotropins to cause overstimulation of the ovary. Support for this idea comes from studies with goldfish that have shown that plasma gonadotropin titers in fish given a dose of LH-RHa and pimozide sufficient to cause ovulation are similar to those observed in individuals during a natural ovulatory cycle (Chang and Peter 1983).

Ovulation has been induced in fishes with 1$300 \mu \mathrm{g} \mathrm{LH}-\mathrm{RHa} / \mathrm{kg} \mathrm{BW}$ and 1-10 mg pimozide/ kg BW (Donaldson and Hunter 1983; Sokolowska et al. 1984; de Leeuw et al. 1985). Both singleand multiple-injection protocols have been used with a variety of LH-RHa, pimozide, and gonadotropin combinations. However, studies to date have largely been confined to cyprinids and salmonids (Peter 1983). There is a lack of information on effective doses and treatments in other species, particularly marine fishes.

Results of this preliminary study demonstrate that a combined LH-RHa and pimozide treatment is useful in inducing ovulation in orangemouth corvina. This treatment may also be useful for inducing ovulation in other species that have been difficult to breed by traditional methods in captivity. There is a need for more studies, utilizing a wider range of species, to determine the general applicability of this technique and to establish effective doses and injection protocols that will be of practical use to fish culturists.

Acknowledgments. - Sincere thanks go to the staff of the California Department of Fish and Game, Inland Fisheries, and members of the Salton Sea Fish and Wildlife Club for assistance in collecting study fish. Thanks also go to R. Howells, C. Jordan, A. Lee, and C. Shaw for data collection and aquaria maintenance. This study was partially supported by a grant to $P$. Thomas from the Texas Advanced Technology Research Program.

\section{References}

Chang, J. P., A. F, Cook, and R. E. Peter. 1983. Influence of catecholamines on gonadotropin secretion 
in goldfish, Carassius auratus. General and Comparative Endocrinology 49:22-31.

Chang, J. P., and R. E. Peter. 1983. Effects of pimozide and des Gly ${ }^{10},\left[\mathrm{D}-\mathrm{Ala}^{6}\right]$-luteinizing hormone-releasing hormone ethylamide on serum gonadotropin concentrations, germinal vesicle migration, and ovulation in female goldfish; Carassius auratus. General and Comparative Endocrinology 52:30-37.

de Leeuw, R., J. W. Resink, E. J. M. Rooyakhers, and H. J. T. Goos. 1985. Pimozide modulates the luteinizing hormone-releasing hormone effect on gonadotropin release in the African catfish, Clarias lazera. General and Comparative Endocrinology 58: 1-9.

Donaldson, E. M., and G. A. Hunter, 1983. Induced final maturation, ovulation, and spermiation in cultured fish. Pages 351-404 in W. S. Hoar, D. J. Randall, and E. M. Donaldson, editors. Fish physiology, volume 9. Part B. Academic Press, New York.

Groves, D. J., and T. F. C. Batten. 1986. Direct control of the gonadotroph in a teleost, Poecilia latipinna.
II. Neurohormones and neurotransmitters. General and Comparative Endocrinology 62:315-326.

Peter, R. E. 1983. The brain and neurohormones in teleost reproduction. Pages 97-136 in W. S. Hoar, D. J. Randall, and E. M. Donaldson, editors. Fish physiology, volume 9. Part A. Academic Press, New York.

Prentice, J. A., and R. L. Colura. 1984. Preliminary observations of orangemouth corvina spawn inducement using photoperiod, temperature and salinity cycles. Journal of the World Mariculture Society $15: 162-171$.

Sherwood, N., L. Eiden, M. Brownstein, J. Spiess, J. Rivier, and W. Vale. 1983. Characterization of a teleost gonadotropin-releasing hormone. Proceedings of the National Academy of Sciences of the United States of America 80:2794-2799.

Sokolowska, M., and six coauthors. 1984. Induction of ovulation in goldfish, Carassius auratus, by pimozide and analogues of LH-RH. Aquaculture 36: 71-83. 
$\bullet$ 
Dispersal of this publication conforms with Texas State Documents Depository Law, and it is available at Texas State Publications

Clearinghouse and Texas Depository Libraries.

PWD-RP-3200-257-8/87 